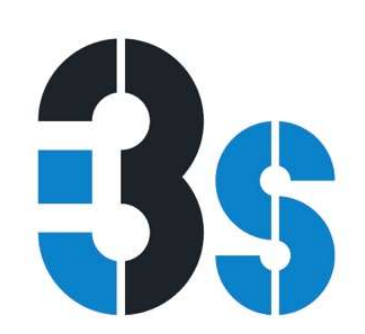

\title{
Review on the use of zebrafish embryos to study the effects of anesthetics during early development
}

\section{Luís Félix, Ana M Coimbra, Ana M Valentim, Luís Antunes}

Originally published in: Félix, L., Coimbra, A. M., Valentim, A. M., \& Antunes, L. (2019). Review on the use of zebrafish embryos to study the effects of anesthetics during early development. Critical reviews in toxicology, 1-14. (https://doi.org/10.1080/10408444.2019.1617236).

\section{ABSTRACT}

Over the years, the potential toxicity of anesthetics has raised serious concerns about its safe use during pregnancy. As evidence emerged from research in animal models, showing that some anesthetic drugs are potential teratogenic, the determination of the risk of exposures to anesthetic drugs at early life stages became mandatory. However, due to inaccessibility and ethical constrains related to experimental conditions, the use of early life stages in mammalian models is limited. In this regard, some animal and nonanimal models have been suggested to surpass mammalian use in experimentation. Among them, the zebrafish embryo test has been recognized as a promising alternative in toxicology research, as well as an inexpensive and practical test. Substantial information collected from developmental research following compounds exposure, has contributed to the application of zebrafish assays in research, although only a few studies have focused on the use of early life stages of zebrafish to evaluate the developmental effects of anesthetics. Based on the recent advances of science and technology, there is a clear potential for zebrafish early life stages to provide new insights into anesthetics teratogenicity. This review provides an overview of recent anesthesia research using zebrafish embryos, demonstrating its usefulness to the anesthesia field, discussing the recent findings on various aspects related to the effects of anesthetics during early life development and the strengths and limitations of this model system.

\section{INTRODUCTION}

Little is known about the long-term impacts of many anesthetic agents during pregnancy and their outcomes to the fetus, which is of concern; it is estimated that around $0.5-2 \%$ of pregnant women require nonobstetric surgery involving anesthesia (Allaert et al. 2007; Reitman and Flood 2011). In 
recent years, the understanding of the physiology and cellular biology of anesthesia on the developing brain has emerged from different studies in various species (Cottrell and Hartung 2012; Andropoulos 2018). These have originated a debate about the safety of anesthetics drugs and their adverse consequences to the central nervous system (CNS) development (Sun 2010; Hudson and Hemmings 2011; Vutskits and Davidson 2017; Culley and Avram 2018), thus, drawing the attention of international organizations (Zhou and Ma 2014; Andropoulos and Greene 2017). In this sense, many efforts have been made over the years, but questions remain unanswered concerning the pharmacotoxicity of anesthetic drugs during early development. Indeed, until now, the clinical data available relative to these drugs in early developmental stages are inconclusive and based only on epidemiological studies (Sanders et al. 2013; Kang et al. 2017; Vutskits and Davidson 2017). Furthermore, critical periods such as organogenesis (from the 3 rd to the 8th week of gestation in humans) are not accessible for analysis in nonhuman primate embryos, thereby limiting embryological studies (Ostrer et al. 2006). In addition to the technical difficulties, the use of animals rise ethical issues (Festing and Wilkinson 2007). Therefore, the use of animal models and in vitro cellular or tissue preparations in embryological research is critical to study the toxicological and mechanistic responses of anesthetics (Schumann 2010; Saint-Raymond and de Vries 2016). However, animal ethics is a very important issue that has been a subject of heated debate for many years (Festing and Wilkinson 2007). This is particularly interesting and challenging considering studies using early developmental stages as critical period varies from species to species (Dobbing and Sands 1979). On the other hand, in vitro methods have been established for the assessment of anesthetics toxicity in early developmental stages (Olsen and Brambrink 2013) and, although in vitro studies remove some of the ethical issues concerning human and other animals' embryo studies, they are not equivalent to whole-animal experiments. In response to this dilemma, the principle of Replacement, part of the ${ }_{3}$ Rs (Replacement, Reduction, and Refinement) principle to the use of animals for scientific purposes has been implemented over the years (Schechtman 2002). Replacement consists of the proposal of several alternatives to animal models to overcome ethical issues, as the use of in vitro models or early life stages of zebrafish; this last approach, as also uses animals, is often called a relative replacement (Redmond 2014). In vitro models help to study biological responses and mechanisms related to human health and disease, but they are not equivalent to whole-animal experiments. Therefore, early life stages of zebrafish have become an alternative to mammalian testing in toxicology and biomedical research, especially due to genetic, developmental, and brain similarities (Doke and Dhawale 2015). These similarities raise some concern particularly when zebrafish is used with the claim that experiments cause less harm in this animal model. However, zebrafish can only be used as replacement up to 5 days postfertilization (dpf), i.e. when the yolk reserves are still present and before it can feed independently (EU 2010). From the legal point of view, prior to yolk depletion, the embryos and larvae do not account as protected animals (Strahle et al. 2012). It is considered that when the animal starts to feed independently, it also develops behaviors and mechanisms to chase preys and escape from predators, being this moment an approximate cue to the activity of relevant neuroanatomical features thought to be consistent with the capacity to experience pain or suffering. Thus, in safety pharmacological investigations and toxicology studies, zebrafish models are in a strategic place to predict toxicity of drugs since these experiments are complex, expensive, and time consuming when higher vertebrate models are used, and in vitro models are too simple (Figure 1). In fact, some of the earliest works to understand the fundamentals of general anesthetics and their mechanism of action were performed in this teleost fish. Therefore, this review describes the current knowledge on the toxicological effects associated with the use of anesthetics in the early life stages of the lower 
vertebrate zebrafish and reviews evidence of the use of this animal model to provide insights into the molecular basis of anesthesia.

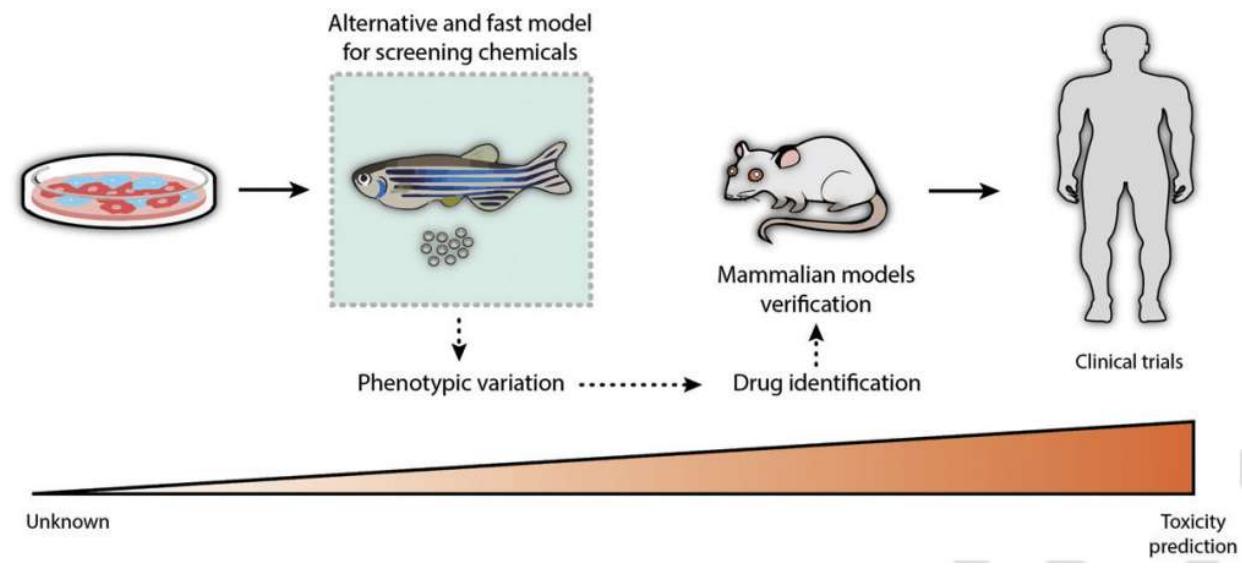

Figure 1: The zebrafish model as a tool to anesthesia toxicity screening. Anesthesia research may benefit from the zebrafish as an alternative to other animal models, overcoming practical and/or ethical reasons from experiments with higher vertebrates. Zebrafish embryos and larvae may be used after in vitro (e.g. cell lines) studies and before mammalian animal models. The developmental process of zebrafish is highly comparable to that of mammals allowing an alternative and fast route for screening and identification of chemicals before preclinical evaluation in mammalian models.

\section{An overview on the importance of the zebrafish model}

Over the last decade, the number of publications listed in PubMed with zebrafish has duplicated (from 1548 in 2007 to 3503 in 2018), in part due to its applicability to study processes with relevance to human health (Barros et al. 2008). In fact, the zebrafish embryo has gained an important role for pediatric research (Ali et al. 2011). There are several advantages in using this model comparative to other animal models (Giacomotto and Segalat 2010), which have been extensively reviewed elsewhere (Veldman and Lin 2008; Ali et al. 2011; Vliegenthart et al. 2014). Briefly, this model has a low cost, small size, high fecundity, genetic similarity (around 70\%) with humans and rapid growth (embryos hatch within $72 \mathrm{~h}$ postfertilization (hpf)-Figure 2-and reach sexual maturity at approximately $3-4$ months), thus, allowing feasible longitudinal studies (Soares et al. 2009; Coimbra et al. 2015). Moreover, zebrafish embryogenesis is non-placental, external to the mother, and all stages of development are visually accessible under light microscope during the first days of development (Kimmel et al. 1995; Westerfield 2000; Spence et al. 2008; Truong et al. 2011; Strahle et al. 2012). Indeed, the transparency of zebrafish embryos allows the application of visualization techniques that, with intra-uterine embryos, would be difficult or uneconomical. Furthermore, the similar neurodevelopment of the zebrafish embryo in comparison with other vertebrate models (Appel 2000; Lewis and Eisen 2003; Saint-Amant 2006; Schmidt et al. 2013; Semple et al. 2013; Oosterhof et al. 2015), whose hallmarks are presented in Figure 3, supports its application as a complementary tool to conventional models to fill the gap between simple in vitro cell-based assays 
and more complex whole animal systems for toxicity screening in early stages (Ali et al. 2011). In fact, the effects of anesthetics in the development can be detected very early, as the first spontaneous movements are detected at $17 \mathrm{hpf}$ (Saint-Amant and Drapeau 1998); the progenitors of tissues and organs are formed at $36 \mathrm{hpf}$ (Spence et al. 2008; Taylor et al. 2010) and active avoidance behaviors at $120 \mathrm{hpf}$ (Spence et al. 2008). Despite the advances in the knowledge of these processes and in the zebrafish embryonic development, the understanding of the developmental effects of anesthetics drugs is still limited. In this sense, studies have been conducted using zebrafish early life stages to explore anesthetics' effects on development and their potential toxicity mechanisms.

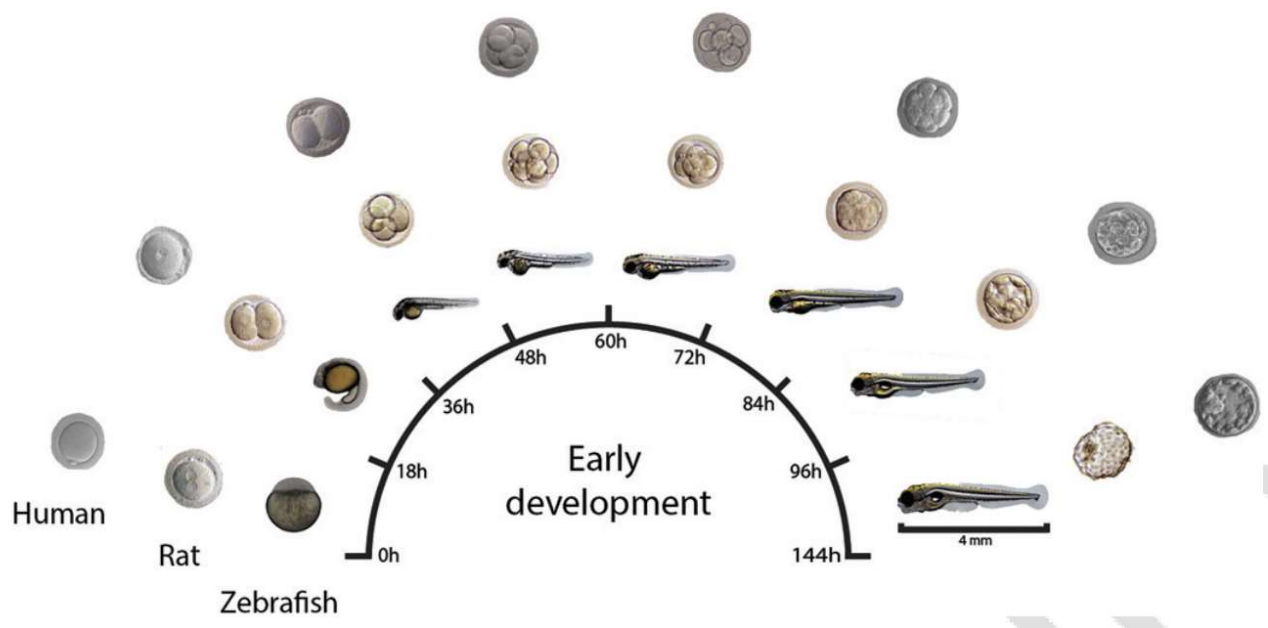

Figure 2. Translating times across human, rat, and zebrafish early development. The human embryo and rodent development are very similar with only slight differences between species. In both cases, up to 144 hpf (hours postfertilization), only a cluster of cells that will originate the blastocyst are observed. By the contrary, the embryonic development of zebrafish is very rapid and morphologically different with all major organs formed in the first $24 \mathrm{hpf}$ and within $72 \mathrm{hpf}$, the fish hatch and start swimming. Human embryo images via Wikimedia Commons; rodent images adapted from Veeck and Zaninovic (2003) and $\mathrm{Q}_{3}$; Zebrafish images were adapted from "Go Fish!" (2009) poster from Genesis. h: hours.

\section{Developmental toxicity of anesthetic drugs in zebrafish}

Despite zebrafish brain being simpler than the rodents and mammalian brain, its formation, differentiation, and connectivity of neurons require molecular mechanisms that appear to be conserved in all vertebrates (Tropepe and Sive 2003). Similarly the counterparts of mammalian brain subdivisions are morphologically identifiable in zebrafish larva (Nishimura et al. 2015). A comparative neuroanatomy at the time at which neurons differentiate into mature neurons is present in Figure 4 . Although the telencephalon is everted and not evaginated like in mammals, the lateral pallium of teleost's appears to be structurally homologous to the mammalian hippocampus, instead of the medial pallium from which derivate in humans (Rodriguez et al. 2002). Understanding these 
differences and particularities will increase the translational potential of the research results. Still, zebrafish embryonic development is much faster; the nervous system is formed at $1 \mathrm{dpf}$ and by $3 \mathrm{dpf}$, the blood-- brain barrier is observed (Jeong et al. 2008).

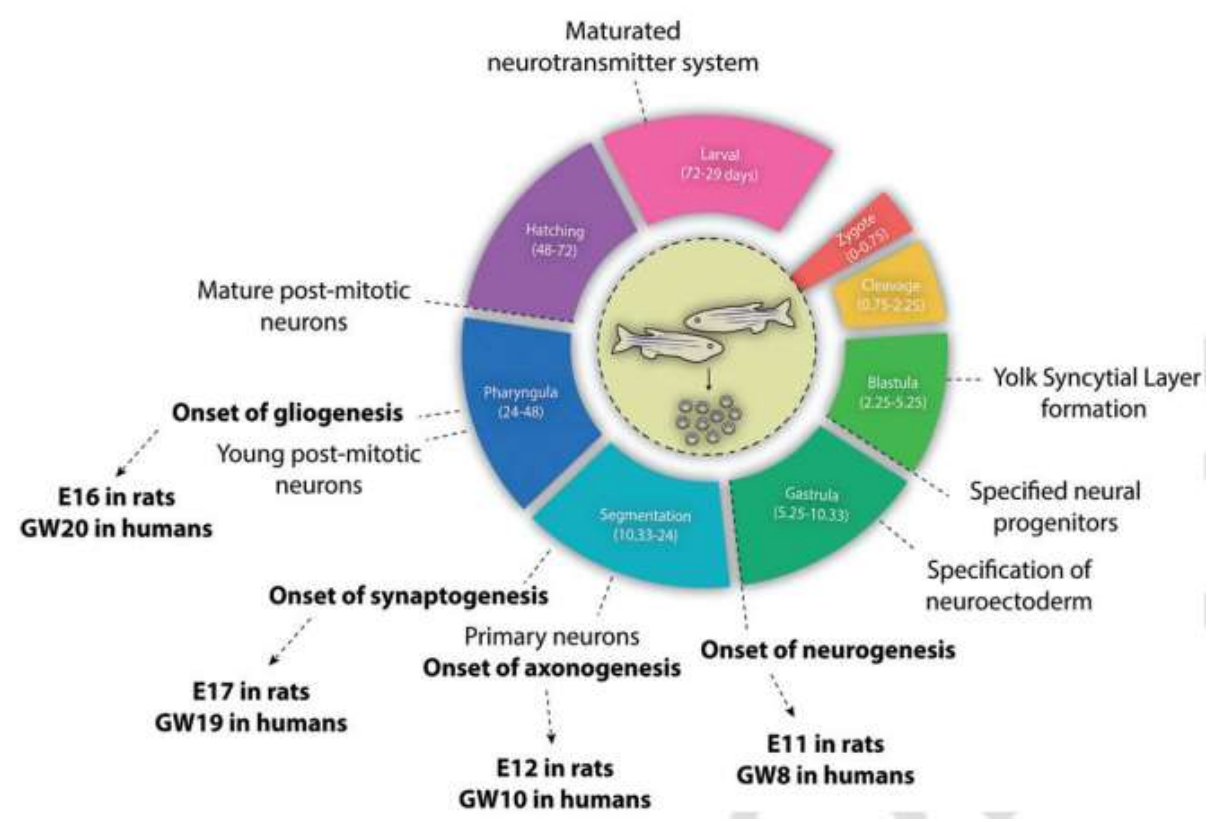

Figure 3: Hallmarks of neurodevelopment during zebrafish development and the corresponding embryonic day (E) or gestational week (GW) in rats and humans, respectively. The formation of neural progenitors during early stages accompanied by an increase in cell proliferation are the first steps in the induction of the neuroectoderm which gives rise to the central and peripheral nervous systems, culminating in the generation of mature neurons. Key neurodevelopmental processes where anesthetics may interfere are presented in bold. Numbers between parenthesis represent hours postfertilization.

The major neurotransmitter systems in zebrafish are detected between 20 and $24 \mathrm{hpf}$ (Higashijima et al. 2004; Cox et al. 2005; Panula et al. 2010; Rico et al. 2011; Horzmann and Freeman 2016) and, at $5 \mathrm{dpf}$, the larvae already present a maturated neurotransmitter system and a broad range of behaviors (Schneider 2017). In humans, neurotransmitters may be found as soon as the egg is fertilized but the major neurotransmitter systems appear around the 13th gestational week while in rats they appear around embryonic day 16 (Herlenius and Lagercrantz 2001; Ritter et al. 2001; Semple et al. 2013). However, and despite their functionalities, their quantity change during pre and postnatal development (Herlenius and Lagercrantz 2001). Anesthetics acts at the CNS mainly through mechanisms that involve voltage-gated channels and neurotransmitter systems. However, the anesthetic teratogenicity may be independent of the main mechanism of action of the anesthetics (Felix et al. 2014, 2018). Nevertheless, several studies showed the influence of anesthetics in the modulation of neurodevelopmental processes, which may result in neurotoxic damage in the immature brain and in long-term behavioral effects (Gohlke et al. 2008; Rand-Weaver et al. 2013). In 
fact, the developing brain is particularly vulnerable to anesthetics exposure during neurodevelopmental processes such as neurogenesis, synaptogenesis, and immature glial development (Lei et al. 2012). In order to promote developmental effects, an anesthetic drug must be administrated in a dose sufficient to induce a particular defect in a fetus/embryo during a critical development point (Upadya and Saneesh 2016). The findings concerning the use of anesthetic drugs in early zebrafish developmental stages are summarized in Table 1 and described below. A selection of studies regarding the effects of some main anesthetics in early phase of development of zebrafish, and potential implications in clinical practice are showed. It is worth noting that in early zebrafish developmental stages, substances are mainly tested by immersion in a bath at the desired concentration, but microinjection can also be an alternative method of administration (Schubert et al. 2014). The use of an immersion bath of anesthetics is similar to the use of volatile agents in mammals, as, in both cases, the intake of the anesthetics is by inhalation. When zebrafish larvae are used, this uptake is through rudimentary gills (depending of the larval stage) and/or through the skin (Martins et al. 2018). During the embryo stages, the anesthetic has to enter into the chorion before reaching the embryo, and so the concentrations in the embryos have to be measured to understand which concentration is really causing an impact (Felix et al. 2016). Despite of this, the concentrations used in zebrafish might not be so distant from those found in humans' plasma (Robinson et al. 2016).

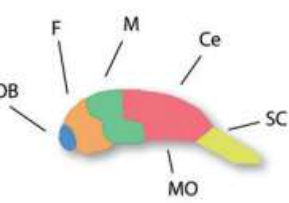

$48 \mathrm{hpf}$

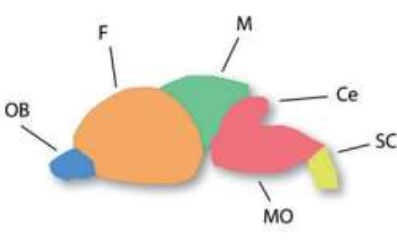

E16

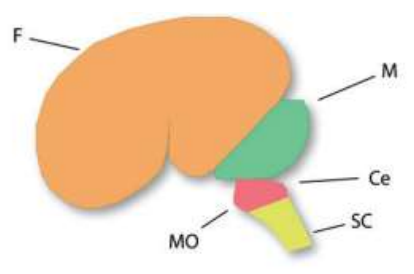

GW13

Figure 4: Brain comparative neuroanatomy across zebrafish, rat, and human at the time the major neurotransmitter systems are detected. In zebrafish, major neurotransmitters may be found as soon as 48 hpf (hours postfertilization). In comparison, major neurotransmitters are found in rats around embryonic day 16 (E16) and in humans around gestational week 13 (GW13). Ce: cerebellum (Ce and MO are part of the hindbrain); F: forebrain; M: midbrain; MO: medulla oblongata; OB: olfactory bulb; Sc: spinal cord.

\section{1: Ketamine}

Ketamine is the most studied anesthetic in zebrafish early development. Ketamine is a noncompetitive N-methyl-daspartate (NMDA) receptor antagonist (Sleigh et al. 2014) which induces sedation, hypnosis, and some analgesia. In human medical settings, its dissociation effects are noticed at concentrations around $0.2-0.4 \mathrm{nM}$, while hypnosis is obtained with concentrations 20higher, around $8 \mathrm{mM}$ (Sleigh et al. 2014). In humans, ketamine can be found at a higher concentration in fetal blood than in maternal blood, and it has been advised for use in late pregnancy in low concentrations (Walton and Melachuri 2006; Neuman and Koren 2013). However, the potential implications to the fetus of ketamine exposure are not fully understood. Previous research studies have highlighted the effects of ketamine in zebrafish early developmental stages. The first study exploring ketamine effects in the early life stages of the zebrafish dates back to 2007 when Burgess and Granato treated zebrafish larvae with 0.1-3.0 mM ketamine for $20 \mathrm{~min}$ and observed altered

INSTITUTO

DE INVESTIGGAC̄̃O

E INOVAÇA

EM SAUDE

DO PORTO

Rua Alfredo Allen, 208 4200-135 Porto

Portugal

+351 220408800

info@i3s.up.pt

www.i3s.up.pt 
sensorimotor gating (Burgess and Granato 2007). Using a similar approach, exposure to a ketamine concentration of $0.5 \mathrm{mM}$ induced changes in startle habituation and startle sensitivity (Wolman et al. 2011). More recently, a dose-dependent effect on the heart rate of 26 and 52 hpf dechorionated zebrafish embryos and changes in mitogen-activated protein kinase (MAPK) signaling pathway after exposure to $0.5^{-10} \mathrm{mM}$ of ketamine for 2 or $20 \mathrm{~h}$ has been shown (Kanungo et al. 2012). Also, ketamine has been shown to affect spinal motor neurons after $20 \mathrm{~h}$ of exposure to concentrations of 0.5-2.0 mM (Cuevas et al. 2013). The previously described CNS defects induced by ketamine exposure were further corroborated and changes in the expression pattern of genes involved in motor neuron development were detected (Kanungo et al. 2013). The acute administration of ketamine at concentrations ranging from 0.84 to $3.37 \mathrm{mM}$ for 20 min during the blastula period caused teratogenic effects producing a variety of abnormal malformations (Felix et al. 2014). The exposure at later developmental stages (gastrula and segmentation) resulted in a decrease of the malformations observed suggesting an embryonic stage-dependent teratogenicity (Felix et al. 2016). The observed teratogenic effects were associated with an oxidative imbalance that could be the key factor for ketamine toxicity (Felix et al. 2016). Furthermore, using the same methodological approach, ketamine has been shown to induce behavioral alterations (Felix et al. 2017) and apoptosis-related gene expression changes (Felix et al. 2017). It is therefore possible that, the observed teratogenic effect may be a consequence of the association of oxidative stressrelated impairment and apoptosis during ketamine exposure (Felix et al. 2016). Similar malformations, behavioral dysfunctions and p53-dependent apoptosis were observed when exposing embryos for $24 \mathrm{~h}$ during early development at concentrations ranging from 0.21 to $0.38 \mathrm{mM}$ (Felix et al. 2017, 2018), further validating the teratogenic potential of ketamine to this species. After a $24 \mathrm{~h}$ exposure to $2 \mathrm{mM}$ ketamine, $72 \mathrm{hpf}$ embryos showed alterations on cyp19 expression levels and on MAPK pathway, associated with the reduction of estradiol-17b levels that is very important to neurodevelopment and neuroprotection (Trickler et al. 2014). More recently, $52 \mathrm{hpf}$ embryos were treated for $24 \mathrm{~h}$ with $0.1-2.0 \mathrm{mM}$ ketamine, and the anesthetic dose $(2 \mathrm{mM})$ induced a reduction in the serotonergic areas of the brain, and an inhibition of endogenous serotonin metabolism to 5 -hydroxyindole acetic acid (5-HIAA) (Robinson et al. 2015). A later work also reported a dosedependent decrease in dopamine levels and an inhibition of tyrosine hydroxylase and dopamine metabolizing enzyme gene expression changes after applying the same methodology (Robinson et al. 2016). Lately, it has shown the occurrence of developmental toxicity at $96 \mathrm{hpf}$ larvae when exposed for $72 \mathrm{~h}$ at similar concentrations ( $2 \mathrm{mM}$ ). At later stages, 72 hpf, exposure to ketamine for $24 \mathrm{~h}$ induced a dose-dependent overexpression of cyp3a65, a specific drug metabolizing CYP enzyme (Robinson et al. 2017). When treatment occurred at early stages such as gastrula (around $6 \mathrm{hpf}$ ), an overall retardation of the embryo development was observed (Robinson et al. 2017) as described earlier (Felix et al. 2016). In addition, exposure to the same concentration ( $2 \mathrm{mM}$ ) affects bioenergetics and gene expression pathways in the zebrafish embryos reducing ATP levels, mitochondrial membrane potential and the total mitochondrial proteins (Robinson et al. 2018). More recently, a 2-h exposure of $28 \mathrm{hpf}$ embryos to ketamine concentrations closer to the lower values of the human anesthetic range $(2 \mathrm{mM})$ was shown to cause significant effects in the heart rate; furthermore, when exposed for $20 \mathrm{~h}$, the embryos presented a decreased size. Additionally, this longer exposure induced neuron toxicity by decreasing the area occupied by serotonergic neurons in the brain and by reducing tyrosine hydroxylase-immunoreactive neurons (Robinson et al. 2018). In general, current studies have shown that ketamine exposure during early developmental phases is, at a certain degree, harmful to zebrafish development and have helped to validate zebrafish embryos as a rational animal model for the study of the developmental effects of ketamine. Generally, effects in zebrafish were detected when exposure is done as early as $3-52 \mathrm{hpf}$ (corresponding from cleavage to 1-2 months of gestation in humans), using ketamine concentrations

INSTITUTO

DEINVESTİGAÇÃO

EINOVAÇAO

EM SAUDE

DO PORTO

Rua Alfredo Allen, 208 4200-135 Porto

Portugal

$+351220408800$

info@i3s.up.pt

www.i3s.up.pt 
lower (Felix et al. 2014, 2016) or equivalent to human anesthetic plasma concentration (2 mM) (Robinson et al. 2016). However, the molecular mechanism underlying ketamine toxicity in early developmental phases remains elusive and further studies are required; this will be important to establish strategies to ensure a normal development.

\section{2: Propofol}

Propofol is a short-acting, gamma-aminobutyric acid (GABA) receptor agonist; it is also a hypnotic agent widely used in pediatric procedures due to its rapid induction and fast recovery (Key et al. 2010). It is worth noting that under medical situations the mean target propofol concentration required to produce a satisfactory sedation in human is approximately $11 \mathrm{mM}$ (Blayney et al. 2003). Propofol has been considered safe to use during pregnancy, however, there is still a debate regarding subtle associations (Reitman and Flood 2011). Similarly to ketamine, several studies have reported that propofol induced widespread apoptosis and behavioral deficits in the developing rodent models (Creeley et al. 2013; Yu et al. 2013). Yet, little is known about its effects on the cellular and molecular mechanisms during the sensitive early life stages. A recent published work showed that zebrafish embryos exposed to propofol from 6 to $48 \mathrm{hpf}$ at concentrations as low as $1 \mathrm{mM}$ presented aberrant development phenotypes (pericardial cysts, an unconsumed yolk sac, small eyes, bleeding, and a curly spinal cord) and an increase in apoptosis through changes in apoptotic-related gene expression. Moreover, propofol induced the inhibition of myelination basic protein expression, thus, supporting the teratogenic potential of this drug (Guo et al. 2015; Liu et al. 2018). In addition, a dose-dependent loss-of-neural activity was also observed after larvae exposure to propofol concentrations higher than $30 \mathrm{mM}$ (Du et al. 2018). However, additional experiments are required to explore the molecular mechanism underlying the propofol neurotoxic effects in this species.

\section{3: Etomidate}

Etomidate is an intravenous anesthetic that potentiates the GABA neurotransmitter system by altering the transmembrane chloride conductance (Tobias 2015). This compound is an interesting alternative to the most common intravenous anesthetics because etomidate possesses some advantages that make it an attractive option to use in pediatric procedures (Mandt et al. 2012) although its neuronal and cognitive effects remain elusive particularly during early infancy (Nyman et al. 2016). In human neonates and infants clinical settings, the minimal hypnotic plasma concentration is around $1 \mathrm{mM}$ (Su et al. 2015) and no teratogenic effects have been described in the literature for its administration during pregnancy in clinically effective doses. However, there is a lack of adequate and well-controlled studies during gestation and early development for etomidate (Perna et al. 2015). In this regard, a recent study reported that general anesthesia of $6 \mathrm{dpf}$ larval zebrafish has been achieved at concentrations of $30 \mathrm{mM}$, causing the loss of brain functions (Du et al. 2018). Still, further studies are necessary to conclude on the teratogenic potential of this anesthetic.

\section{4: Benzodiazepines}

Benzodiazepines are GABA receptor agonists acting in the CNS to induce sedation, muscle relaxation, some degree of amnesia and anticonvulsant activity (Griffin et al. 2013). Among them,

INSTITUTO

DE INVESTIGACÃO

E INOVAÇÃ

EM SAUDE

DO PORTO

Rua Alfredo Allen, 208 4200-135 Porto

Portugal

+351220408800

info@i3s.up.pt

www.i3s.up.pt 
midazolam is a sedative-hypnotic agent also used in pediatric medicine, and it has been shown to accumulate in zebrafish larvae ( $7 \mathrm{dpf}$ ) after a 3 -h exposure period to concentrations of $1 \mathrm{mM}$ (Alderton et al. 2010). This represents a lower concentration relative to the mean maximum plasma concentration ( $4.47 \mathrm{mM}$ ) following intravenous administration in children (Malinovsky et al. 1993). A similar benzodiazepine, diazepam, administered to zebrafish embryos for 3 days, induced alterations on locomotion ( $1 \mathrm{nM}$ ) and on the genes involved in the circadian rhythm (both at $1 \mathrm{nM}$ and $1 \mathrm{mM}$ ) (Oggier et al. 2010). In addition, 6 dpf zebrafish exposed to higher concentrations (up to $2.5 \mathrm{mM}$ ) of diazepam had motor function impairments, but no alterations on anxiety-like responses (Zahid et al. 2018). As the binding site for benzodiazepines in the brain is described to be highly conserved between fish and mammals (Carr and Chambers 2001), and as there are contradictory data regarding the use of these drugs during pregnancy (Neuman and Koren 2013), zebrafish seems to be a good model to clarify this issue, evaluating possible implications to humans and other animals.

\section{5: Volatile agents}

Inhalation of volatile anesthetics has been the preferred technique in obstetrics and pediatrics. The administration of isoflurane has been associated with accelerated apoptosis and teratological effects in mammals (mice, rats, rhesus macaque, and humans) in concentrations ranging from 32.5 to around 146 mM (Brambrink et al. 2010; Istaphanous et al. 2011; Davidson 2016). The information regarding the effect of these agents in zebrafish larvae is scarce; still, an effective dose of isoflurane for anesthetic purposes of $14.2 \mathrm{mM}$ isoflurane has been established for 7 days postfertilization larvae while a 10 higher concentration has been defined as the mean lethal dose for this species (Ku et al. 2013). More studies with isoflurane and other halogenated anesthetics are important to further assess the potential adverse effects and correspondent toxicity mechanisms of these compounds in early life forms using zebrafish pharmacological assays.

\section{6: Local anesthetics}

Local anesthetics are usually amino amides that act through blockade of the sodium channels of the neuron membrane, interfering with the action potential and thus, preventing propagation of this signal along the axon (Cox et al. 2003). In this sense, the use of local anesthetics might affect indirect cell mitosis and embryogenesis. However, until now, no firm evidence exists that any local anesthetic agent is teratogenic in humans or in rodent models (Ramazzotto et al. 1985; Fujinaga and Mazze 1986; Fleming and Alderton 2013). One example of a local anesthetic used both in mammals and fish is lidocaine. It is usually administered by immersion in fish, and can be used as an analgesic and/or anesthetic. Most studies revealed no teratogenic effects caused by lidocaine at concentrations higher than the ones that are clinically relevant (Fujinaga 1998), but, in an in vitro mouse study, this drug caused neural closure defects ( $O$ 'Shea and Kaufman 1980). More recently, lidocaine concentrations superior to $20 \mathrm{mg} / \mathrm{L}$ (around $74 \mathrm{mM}$, and higher than clinical relevant concentrations) have been shown to induce teratogenic effects on zebrafish embryos ( 2 hpf) exposed for $48 \mathrm{~h}$ (Lomba et al. 2019). Still, there are contradictory results between studies with different rat strains (Teiling et al. 1987; Smith et al. 1989), which may reveal an effect dependent on species and/or strain. Thus, some groups of people may be susceptible to lidocaine teratogenic effects, which needs further genetic evaluation. As zebrafish is a simpler model than rodents, with high genetic homology with humans, this seems to be the adequate animal model to shed light on this issue.

INSTITUTO

DE INVESTİGAÇÃO

EINOVAÇA

UNIVERSIDADE

DO PORTO

Rua Alfredo Allen, 208 4200-135 Porto

Portugal

+351220408800

info@i3s.up.pt

www.i3s.up.pt 


\section{7: Opioids}

These agents include morphine-like agonists, meperidine-like agonists such as meperidine and fentanyl and synthetic opioid analogs (Babb et al. 2010). High doses of opioids are capable of producing anesthesia in humans (Bovill et al. 1984; Vilela et al. 2009), and they are frequently used for pain management during pregnancy, despite evidences of possible adverse effects on fetal development, such as poor fetal growth, preterm birth, birth defects and neonatal abstinence syndrome (Yazdy et al. 2015). However, observational studies in humans are always limited and more research needs to be done. Up until now, no evidence supported the teratogenicity of these compounds in animal models (Fujinaga et al. 1986; Fujinaga and Mazze 1988; Fujinaga et al. 1988). Still, behavioral outcomes following opioids exposure have been linked with changes in brain gene expression (Przewlocki 2004) which have also been described in zebrafish embryos (Herrero-Turrion et al. 2014; Sanchez-Simon et al. 2010). However, some compounds seem to be less harmful in zebrafish than in rodents, such as morphine (Ali et al. 2011) which increased mortality in rodents (Creeley et al. 2013). In zebrafish, opioid effects have been recently reviewed (Demin et al. 2018; Bao et al. 2019). Overall, morphine enhanced cell proliferation, as already seen in mammals, but neuronal differentiation seems to be dependent on the zebrafish embryos age (Sanchez-Simon et al. 2010). Another study revealed the effect of chronic morphine exposure for $19 \mathrm{~h}$ in $5 \mathrm{hpf}$ embryos, where it altered the expression of genes associated with neuronal development, such as CNS patterning processes, differentiation, and neurotransmission (dopaminergic, serotonergic, and glutamatergic) and the activation of axonogenesis and dendritogenesis (Herrero-Turrion et al. 2014). At concentrations lower than those clinically relevant (higher than $245 \mathrm{mM}$ ) (Aguirre et al. 2016), chronic exposure of zebrafish embryos to morphine disrupts the immune responses, similar to what was observed in humans (Mottaz et al. 2017). More recently, behavioral alterations were observed when exposing $120 \mathrm{hpf}$ larvae to concentrations around $3.5 \mathrm{mM}$ (1 mg/L) for $40 \mathrm{~min}$ (Lopez-Luna et al. 2017) and also when $168 \mathrm{hpf}$ were exposed for $1 \mathrm{~h}$ at 10

higher concentrations (Zhou et al. 2018). In addition, when $5 \mathrm{hpf}$ embryos were exposed for $19 \mathrm{~h}$ to morphine concentrations of $10 \mathrm{nM}$ novel evidence has emerged showing a delay in neural stem cells differentiation and changes in the expression of some transcription factors (Jimenez-Gonzalez et al. 2018). Therefore, morphine may pose a risk to early pregnancy, which is worthy of further research.

\section{4: DISCUSSION}

Through the years, concerns have been raised regarding early embryo-fetal development during the prenatal period. Indeed, this period could represent many risks to the developing fetus and to the mother, especially in the beginning when pregnancy symptoms are often unrealized and anesthetics' safety for this condition is not taken into consideration (Goetzl 2010). Moreover, it is estimated that about $2 \%$ of first trimester pregnant women undergo general anesthesia, which might increase the risk of prenatal adverse effects (Allaert et al. 2007; Reitman and Flood 2011). Despite the observed developmental toxicity of anesthetics in animal models, the application of these findings and its translation to humans is still uncertain. The introduction of zebrafish in standard laboratory practices has allowed the investigation of genetic, cellular, morphological, and biochemical mechanisms by which anesthetics induce developmental deficits. Overall, and although no clear mechanism has been described for the developmental effects induced by anesthetics, the references presented here

INSTITUTO

DE INVESTIGGAÇÃO

E INOVAÇA

EM SAUDE

DO PORTO

Rua Alfredo Allen, 208 4200-135 Porto

Portugal

+351220408800

info@i3s.up.pt

www.i3s.up.pt 
and others in the literature present the zebrafish early developmental stages as a robust and complementary promising model to better understand the mechanism of action of these compounds during the neurodevelopmental period (Kanungo et al. 2014; Guo et al. 2015; Felix et al. 2016, 2017; Nishimura et al. 2016; d'Amora and Giordani, 2018). So far, alterations in morphology, behavior, oxidative stress, enzymes, and genetic expression related with apoptosis, proliferation, and other neuronal processes were reported. These findings appear to indicate similar multicellular processes affected by anesthetics in zebrafish development, as well as in rodents and humans. To some extent, the cross-translation is possible due to the highly conserved mechanisms of anesthetics' action in vertebrates (Stewart et al. 2011), indicating that some developmental effects of anesthetics can be similar between zebrafish and higher vertebrates. Also, zebrafish brain morphology, neurochemistry, and neuroendocrine system are homologous to those recognized in mammals (Kalueff et al. 2014). While the mechanisms of action underlying anesthesiainduced embryo-fetal developmental toxicity remain elusive, this review highlights the potential for further studies that can be conducted to examine changes induced by anesthetic compounds in zebrafish. However, there are also some obstacles to this model application to anesthesia research that should be taken into consideration. For instance, despite sharing with mammals a similar, but old diverged ancestor (Woods et al. 2000), zebrafish lacks some organs, such as lungs, limbs, and others (Ali et al. 2011), which prevent the evaluation of anesthetics' effects in these organs. Though, zebrafish has been used to study lung disease by studying neutrophilic inflammation that is responsible for much of the tissue damage seen in many lung diseases (Renshaw et al. 2007; Ljujic et al. 2018). Other difference compared to other vertebrates, is the whole-genome duplication in zebrafish (Woods et al. 2000) which can significantly complicate genetic approaches as gene subfunctionalization and neofunctionalization occurred (Postlethwait et al. 2004). Moreover, from a physiological perspective, zebrafish and humans have very different respiratory systems due to the transition from water to land, leading to the development of a double circulation and progression from ectothermic-heterothermy to endothermic-homeothermy. However, the embryological origin of the fish gills and of the mammalian lungs is the same, the primitive pharynx (Carvalho and Gonc, alves 2011). As zebrafish is a poikilothermic model, it can have different metabolic and clinical responses (induction and recovery times) to the anesthetics (Neiffer and Stamper 2009). In fact, it has already been documented significant variations in oxygen consumption during developmental stages (Bang, Gronkjaer, and Malte 2004; Stackley et al. 2011; Huang et al. 2013). Moreover, the ability to control depth and duration of anesthesia, as well as monitor physiological parameters during early development in this species is a crucial and difficult issue. The control of the anesthesia depth in humans involves technology that does not exist for this small teleost fish. However, even in humans there is no completely/consensual accepted methodology that accurately detects and monitors the depth of general anesthesia (Ferreira et al. 2019) and clinical responses have not been replaced since antiquity. Fish anesthetic delivery is also mainly determined by assessing clinical responses such as activity, reactivity to stimuli, equilibrium, muscle tone, and respiratory and heart rates. Interestingly, fish show the same response as other species when volatile anesthetics are used. Induction usually takes 5-10 min and is marked by a decrease in swimming, respiratory rate, and reaction to stimuli, followed by loss of the equilibrium. The surgical anesthesia stage is observed when the previous measures are further depressed and there is a loss of reaction to painful stimuli. Recovery from anesthesia follows a similar pattern to the mammals' recovery (Sneddon 2012). Additionally, important considerations for modeling anesthesia in zebrafish related to the complexity of brain development and function need to be clarified. In this regard, and despite comparative brain neuroanatomy, which has revealed similar structural properties to higher vertebrates (Kalueff et al. 2014), experimental conditions in zebrafish are still difficult to extrapolate to humans due to differences in the proliferation rates during

INSTITUTO

DE INVESTİGAÇÃO

EINOVAÇAO

EM SAUDE

DO PORTO

Rua Alfredo Allen, 208 4200-135 Porto

Portugal

$+351220408800$

info@i3s.up.pt

www.i3s.up.pt 
neurodevelopmental period of zebrafish (Schmidt et al. 2013; Nishimura et al. 2015), which may induce different vulnerabilities and susceptibilities to anesthetics. Moreover, there is a gap in the knowledge of certain brain functions, as well as in the importance of some CNS structures and their mammalian counterparts, thus, complicating the interpretation of physiological states involving the modulation of a variety of neural circuits. The efficacy and route of administration during early developmental stages are other challenges, as the presence of the chorion up to $48 \mathrm{hpf}$ may hinder the passage of some anesthetics, resulting in different pharmacokinetics. Yet, this can be overcome by a manual or automated chorion-removing process (Bugel et al. 2014) or by drug microinjection. Moreover, drugs which are not water-soluble can be problematic to administer by water immersion and the use of solvents can impact biotransformation of compounds, which is a critical process for the toxic outcome (David et al. 2012). Moreover, the knowledge regarding the characterization of functional metabolic capacities expressed in zebrafish embryos is scarce and pivotal for the correct interpretation of teratogenicity assays (Verbueken et al. 2017). Overall, even considering these limitations, at long-term, zebrafish early life stages may constitute a highly applicable model in advancing anesthesia research with high potential and translational value.

\section{5: CONCLUSION}

This review highlighted the biological advances in anesthesia research that have been facilitated by the use of early developmental stages of zebrafish, providing new and exciting possibilities to understand the prenatal effects of the anesthetics. Through the studies summarized here, some areas and anesthetics were identified as needing more research to clarify potential teratogenic effects and increase the knowledge on brain development and function under anesthesia in early developmental stages. Although some biological problems remain to be addressed with this model, zebrafish will allow the use of a complex organism instead of in vitro techniques and replaces the use of animal models more prone to pain, potentiating knowledge that can be more directly applied to other vertebrates, thereby, facilitating the translational biomedical research and reducing the risks associated in clinical practice.

\section{Declaration of interest}

The authors have nothing to declare. This work was supported by European Investment Funds by FEDER/ COMPETE/POCI- Operational Competitiveness and Internationalization Program, under Project POCl-01-0145-FEDER-006958, POCl-01-0145- FEDER-029542 and FCOMP-01-0124FEDER-028683 and National Funds by FCT - Portuguese Foundation for Science and Technology, under the projects PTDC/CVT-WEL/4672/2012, PTDC/CVT-CVT/29542/2017 and UID/ AGR/04033/2019. This work was also supported by Fundação para a Ciência e a Tecnologia. 


\section{REFERENCES}

Aguirre J, Borgeat A, Hasler M, Buhler P, Bonvini JM. 2016. Clinical concentrations of morphine are cytotoxic on proliferating human fibroblasts in vitro. Eur J Anaesthesiol. 33:832-839.

Alderton W, Berghmans S, Butler P, Chassaing H, Fleming A, Golder Z, Richards F, Gardner I. 2010. Accumulation and metabolism of drugs and CYP probe substrates in zebrafish larvae. Xenobiotica 40:547-557.

Ali S, Champagne DL, Spaink HP, Richardson MK. 2011. Zebrafish embryos and larvae: a new generation of disease models and drug screens. Birth Defects Res C Embryo Today. 93:115-133.

Ali S, van Mil HG, Richardson MK. 2011. Large-scale assessment of the zebrafish embryo as a possible predictive model in toxicity testing. PLoS One. 6:e21076.

Allaert SE, Carlier SP, Weyne LP, Vertommen DJ, Dutre PE, Desmet MB. 2007. First trimester anesthesia exposure and fetal outcome. A review. Acta Anaesthesiol Belg. 58:119-123.

Andropoulos DB. 2018. Effect of anesthesia on the developing brain: infant and fetus. Fetal Diagn Ther. 43:1-11.

Andropoulos DB, Greene MF. 2017. Anesthesia and developing brains - implications of the FDA warning. N Engl J Med. 376:905-907.

Appel B. 2000. Zebrafish neural induction and patterning. Dev Dyn. 219: 155-168. Babb M, Koren G, Einarson A. 2010. Treating pain during pregnancy. Can Fam Phys. 56:25-27.

Bang A, Gronkjaer P, Malte H. 2004. Individual variation in the rate of oxygen consumption by zebrafish embryos. J Fish Biol. 64:1285-1296.

Bao W, Volgin AD, Alpyshov ET, Friend AJ, Strekalova TV, de Abreu MS, Collins C, Amstislavskaya TG, Demin KA, Kalueff AV. 2019. Opioid neurobiology, neurogenetics and neuropharmacology in zebrafish. Neuroscience. 404:218-232.

Barros TP, Alderton WK, Reynolds HM, Roach AG, Berghmans S. 2008. Zebrafish: an emerging technology for in vivo pharmacological assessment to identify potential safety liabilities in early drug discovery. Br J Pharmacol. 154:1400-1413.

Blayney MR, Ryan JD, Malins AF. 2003. Propofol target-controlled infusions for sedation-a safe technique for the non-anaesthetist? Br Dent J. 194:450-452.

Bovill JG, Sebel PS, Stanley TH. 1984. Opioid analgesics in anesthesia: with special reference to their use in cardiovascular anesthesia. Anesthesiology 61:731-755.

Brambrink AM, Evers AS, Avidan MS, Farber NB, Smith DJ, Zhang X, Dissen GA, Creeley CE, Olney JW. 2010. Isoflurane-induced neuroapoptosis in the neonatal rhesus macaque brain. Anesthesiology. 112: 834-841. 
Bugel SM, Tanguay RL, Planchart A. 2014. Zebrafish: a marvel of highthroughput biology for 21st century toxicology. Curr Environ Health Rep. 1:341-352.

Burgess HA, Granato M. 2007. Sensorimotor gating in larval zebrafish. J Neurosci. 27:4984-4994. Carr RL, Chambers JE. 2001. Toxic responses of the nervous system. In: Schlenk E, Benson, W. H., editors. Target organ toxicity in marine and $\mathrm{Q}_{1}$ freshwater teleosts, Taylor and Francis; p. 26-95.

Carvalho O, Gonc, alves C. 2011. Comparative physiology of the respiratory system in the animal kingdom. TOBIO J. 4:35-46.

Coimbra AM, Peixoto MJ, Coelho I, Lacerda R, Carvalho AP, Gesto M, Lyssimachou A, Lima D, Soares J, Andre A, et al. 2015. Chronic effects of clofibric acid in zebrafish (Danio rerio): a multigenerational study. Aquat Toxicol. 160:76-86.

Cottrell JE, Hartung J. 2012. Developmental disability in the young and postoperative cognitive dysfunction in the elderly after anesthesia and surgery: do data justify changing clinical practice? Mt Sinai J Med. 79:75-94.

Cox B, Durieux ME, Marcus MA. 2003. Toxicity of local anaesthetics. Best Pract Res Clin Anaesthesiol. $17: 111-136$.

Cox JA, Kucenas S, Voigt MM. 2005. Molecular characterization and embryonic expression of the family of N-methyl-D-aspartate receptor subunit genes in the zebrafish. Dev Dyn. 234:756-766.

Creeley C, Dikranian K, Dissen G, Martin L, Olney J, Brambrink A. 2013. Propofol-induced apoptosis of neurones and oligodendrocytes in fetal and neonatal rhesus macaque brain. Br J Anaesth. 110:i2938.

Cuevas E, Trickler WJ, Guo X, Ali SF, Paule MG, Kanungo J. 2013. Acetyl L-carnitine protects motor neurons and Rohon-Beard sensory neurons against ketamine-induced neurotoxicity in zebrafish embryos. Neurotoxicol Teratol. 39:69-76.

Culley DJ, Avram MJ. 2018. Young brain and anesthesia: Refusal of anesthesia Is not an option! Anesthesiology. 128:697-699. d'Amora M, Giordani S. 2018. The utility of zebrafish as a model for screening developmental neurotoxicity. Front Neurosci. 12:976.

David RM, Jones HS, Panter GH, Winter MJ, Hutchinson TH, Kevin Chipman J. 2012. Interference with xenobiotic metabolic activity by the commonly used vehicle solvents dimethylsulfoxide and methanol in zebrafish (Danio rerio) larvae but not Daphnia magna. Chemosphere. 88:912-917.

Davidson A. 2016. The effect of anaesthesia on the infant brain. Early Hum Dev. 102:37-40. Demin KA, Meshalkina DA, Kysil EV, Antonova KA, Volgin AD, Yakovlev OA, Alekseeva PA, Firuleva MM, Lakstygal AM, de Abreu MS, et al. 2018. Zebrafish models relevant to studying central opioid and endocannabinoid systems. Prog Neuropsychopharmacol Biol Psych. 86:301-312.

Dobbing J, Sands J. 1979. Comparative aspects of the brain growth spurt. Early Hum Dev. 3:79-83. Doke SK, Dhawale SC. 2015. Alternatives to animal testing: a review. Saudi Pharm J. 23:223-229. 
Du WJ, Zhang RW, Li J, Zhang BB, Peng XL, Cao S, Yuan J, Yuan CD, Yu T, Du JL. 2018. The locus coeruleus modulates intravenous general anesthesia of zebrafish via a cooperative mechanism. Cell Rep. 24: 3146-3155 e3.

EU. 2010. Directive 2010/63/EU of the European Parliament and of the Council of 22 September 2010 on the protection of animals used for scientific purposes. Off J Eur Union. 276:33-79.

Felix LM, Antunes LM, Coimbra AM. 2014. Ketamine NMDA receptor-independent toxicity during zebrafish (Danio rerio) embryonic development. Neurotoxicol Teratol. 41:27-34.

Felix LM, Antunes LM, Coimbra AM, Valentim AM. 2017. Behavioral alterations of zebrafish larvae after early embryonic exposure to ketamine. Psychopharmacology (Berl). 234:549-558.

Felix LM, Luzio A, Themudo M, Antunes L, Matos M, Coimbra AM, Valentim AM. 2018. MS-222 short exposure induces developmental and behavioural alterations in zebrafish embryos. Reprod Toxicol. 81: 122-131.

Felix LM, Serafim C, Martins MJ, Valentim AM, Antunes LM, Matos M, Coimbra AM. 2017. Morphological and behavioral responses of zebrafish after $24 \mathrm{~h}$ of ketamine embryonic exposure. Toxicol Appl Pharmacol. 321:27-36.

Felix LM, Serafim C, Valentim AM, Antunes LM, Campos S, Matos M, Coimbra AM. 2016. Embryonic stage-dependent teratogenicity of ketamine in zebrafish (Danio rerio). Chem Res Toxicol. 29:12981309 .

Felix LM, Serafim C, Valentim AM, Antunes LM, Matos M, Coimbra AM. 2017. Apoptosis-related genes induced in response to ketamine during early life stages of zebrafish. Toxicol Lett. 279:1-8.

Felix LM, Vidal AM, Serafim C, Valentim AM, Antunes LM, Campos S, Matos M, Monteiro SM, Coimbra AM. 2016. Ketamine-induced oxidative stress at different developmental stages of zebrafish (Danio rerio) embryos. Rsc Adv. 6:61254-61266.

Felix LM, Vidal AM, Serafim C, Valentim AM, Antunes LM, Monteiro SM, Matos M, Coimbra AM. 2018. Ketamine induction of $\mathrm{p} 53$-dependent apoptosis and oxidative stress in zebrafish (Danio rerio) embryos. Chemosphere. 201:730-739.

Ferreira AL, Nunes C, Mendes JG, Amorim P. 2019. Do we have today a reliable method to detect the moment of loss of consciousness during induction of general anaesthesia? Rev Esp Anestesiol Reanim. 66: 93-103.

Festing S, Wilkinson R. 2007. The ethics of animal research. Talking point on the use of animals in scientific research. EMBO Rep. 8:526-530.

Fleming A, Alderton WK. 2013. Zebrafish in pharmaceutical industry research: finding the best fit. Drug Discov Today Dis Models. 10: e43-e50. Fujinaga M. 1998. Assessment of teratogenic effects of lidocaine in rat embryos cultured in vitro. Anesthesiology. 89:1553-1558. 
Fujinaga M, Mazze RI. 1986. Reproductive and teratogenic effects of lidocaine in Sprague-Dawley rats. Anesthesiology. 65:626-632.

Fujinaga M, Mazze Rl. 1988. Teratogenic and postnatal developmental studies of morphine in Sprague-Dawley rats. Teratology. 38:401-410.

Fujinaga M, Mazze RI, Jackson EC, Baden JM. 1988. Reproductive and teratogenic effects of sufentanil and alfentanil in Sprague-Dawley rats. Anesth Anal. 67:166-169.

Fujinaga M, Stevenson JB, Mazze RI. 1986. Reproductive and teratogenic effects of fentanyl in Sprague-Dawley rats. Teratology. 34:51-57.

Giacomotto J, Segalat L. 2010. High-throughput screening and small animal models, where are we? Br J Pharmacol. 160:204-216.

Go Fish! 2009. Genesis, 47.

Goetzl L. 2010. Adverse pregnancy outcomes after abnormal first-trimester screening for aneuploidy. Clin Lab Med. 30:613-628.

Gohlke JM, Hiller-Sturmhofel S, Faustman EM. 2008. A systems-based computational model of alcohol's toxic effects on brain development. Alcohol Res Health. 31:76-83.

Griffin CE, 3rd, Kaye AM, Bueno FR, Kaye AD. 2013. Benzodiazepine pharmacology and central nervous system-mediated effects. Ochsner J. 13:214-223.

Guo P, Huang Z, Tao T, Chen X, Zhang W, Zhang Y, Lin C. 2015. Zebrafish as a model for studying the developmental neurotoxicity of propofol. J Appl Toxicol. 35:1511-1519.

Herlenius E, Lagercrantz H. 2001. Neurotransmitters and neuromodulators during early human development. Early Hum Dev. 65:21-37.

Herrero-Turrion MJ, Rodriguez-Martin I, Lopez-Bellido R, Rodriguez RE. 2014. Whole-genome expression profile in zebrafish embryos after chronic exposure to morphine: identification of new genes associated with neuronal function and mu opioid receptor expression. BMC Genomics. 15:874.

Higashijima S, Mandel G, Fetcho JR. 2004. Distribution of prospective glutamatergic, glycinergic, and GABAergic neurons in embryonic and larval zebrafish. J Comp Neurol. 480:1-18.

Horzmann KA, Freeman JL. 2016. Zebrafish get connected: investigating neurotransmission targets and alterations in chemical toxicity. Toxics. 4:19.

Huang SH, Huang KS, Yu CH, Gong HY. 2013. Metabolic profile analysis of a single developing zebrafish embryo via monitoring of oxygen consumption rates within a microfluidic device. Biomicrofluidics. 7: 64107. 
Hudson AE, Hemmings HC. Jr. 2011. Are anaesthetics toxic to the brain? Br J Anaesth. 107:30-37. Istaphanous GK, Howard J, Nan X, Hughes EA, McCann JC, McAuliffe JJ, Danzer SC, Loepke AW. 2011. Comparison of the neuroapoptotic properties of equipotent anesthetic concentrations of desflurane, isoflurane, or sevoflurane in neonatal mice. Anesthesiology. 114:578-587.

Jeong JY, Kwon HB, Ahn JC, Kang D, Kwon SH, Park JA, Kim KW. 2008. Functional and developmental analysis of the blood-brain barrier in zebrafish. Brain Res Bull. 75:619-628.

Jimenez-Gonzalez A, Garcia-Concejo A, Leon-Lobera F, Rodriguez RE. 2018. Morphine delays neural stem cells differentiation by facilitating Nestin overexpression. Biochim Biophys Acta Gen Subj. 1862:474-484.

Kalueff AV, Stewart AM, Gerlai R. 2014. Zebrafish as an emerging model for studying complex brain disorders. Trends Pharmacol Sci. 35:63-75.

Kang E, Berg DA, Furmanski O, Jackson WM, Ryu YK, Gray CD, Mintz CD. 2017. Neurogenesis and developmental anesthetic neurotoxicity. Neurotoxicol Teratol. 60:33-39.

Kanungo J, Cuevas E, Ali SF, Paule MG. 2012. L-Carnitine rescues ketamine-induced attenuated heart rate and MAPK (ERK) activity in zebrafish embryos. Reprod Toxicol. 33:205-212.

Kanungo J, Cuevas E, Ali SF, Paule MG. 2013. Ketamine induces motor neuron toxicity and alters neurogenic and proneural gene expression in zebrafish. J Appl Toxicol. 33:410-417.

Kanungo J, Cuevas E, Ali SF, Paule MG. 2014. Zebrafish model in drug safety assessment. Curr Pharm Des. 20:5416-5429.

Key KL, Rich C, DeCristofaro C, Collins S. 2010. Use of propofol and emergence agitation in children: a literature review. Aana J. 78:468-473.

Kimmel CB, Ballard WW, Kimmel SR, Ullmann B, Schilling TF. 1995. Stages of embryonic development of the zebrafish. Dev Dyn. 203:253-310.

Ku T-H, Ken C-F, Yang S-F, Tsao Y-M, Chen G, Tang C-Y. 2013. Isoflurane anesthesia EC50 and LC50 for zebrafish: 9AP5-8. Eur J Anaesthesiol. 30:153-154.

Veeck LL, Zaninovic N. 2003. An atlas of human blastocysts. New York: Parthenon Publishing Group.

Lei X, Guo Q, Zhang J. 2012. Mechanistic insights into neurotoxicity induced by anesthetics in the developing brain. Int J Mol Sci. 13: 6772-6799.

Lewis KE, Eisen JS. 2003. From cells to circuits: development of the zebrafish spinal cord. Prog Neurobiol. 69:419-449.

Liu C, Lin C, Guo P, Zhang X, Zhu X. 2018. Exposure to propofol downregulates myelin basic protein expression in zebrafish embryos: its neurotoxicity on oligodendrocytes and the molecular mechanisms. Nan Fang Yi Ke Da Xue Xue Bao 38:1115-1120. 
Ljujic M, Varga M, Bartel S, Krauss-Etschmann S, Divac Rankov A. 2018. Zebrafish as a model for study of developmental origins of chronic lung diseases. Eur Respir J. 52:PA1389.

Lomba L, Ribate MP, Zuriaga E, Garcia CB, Giner B. 2019. Acute and subacute effects of drugs in embryos of Danio rerio. QSAR grouping and modelling. Ecotoxicol Environ Saf. 172:232-239.

Lopez-Luna J, Al-Jubouri Q, Al-Nuaimy W, Sneddon LU. 2017. Reduction in activity by noxious chemical stimulation is ameliorated by immersion in analgesic drugs in zebrafish. J Exp Biol. 220:1451-1458.

Malinovsky JM, Lejus C, Servin F, Lepage JY, Le Normand Y, Testa S, Cozian A, Pinaud M. 1993. Plasma concentrations of midazolam after i.v., nasal or rectal administration in children. $\mathrm{Br} J$ Anaesth. 70: 617-620.

Mandt MJ, Roback MG, Bajaj L, Galinkin JL, Gao D, Wathen JE. 2012. Etomidate for short pediatric procedures in the emergency department. Pediatr Emerg Care. 28:898-904.

Martins T, Diniz E, Felix LM, Antunes L. 2018. Evaluation of anaesthetic protocols for laboratory adult zebrafish (Danio rerio). PLoS One. 13: e0197846.

Mottaz H, Schonenberger R, Fischer S, Eggen RIL, Schirmer K, Groh KJ. 2017. Dose-dependent effects of morphine on lipopolysaccharide (LPS)-induced inflammation, and involvement of multixenobiotic resistance (MXR) transporters in LPS efflux in teleost fish. Environ Pollut. 221:105115 .

Neiffer DL, Stamper MA. 2009. Fish sedation, analgesia, anesthesia, and euthanasia: considerations, methods, and types of drugs. Ilar J. 50: 343-360.

Neuman G, Koren G. 2013. Motherisk rounds: safety of procedural sedation in pregnancy. J Obstet Gynaecol Can. 35:168-173.

Nishimura Y, Inoue A, Sasagawa S, Koiwa J, Kawaguchi K, Kawase R, Maruyama T, Kim S, Tanaka T. 2016. Using zebrafish in systems toxicology for developmental toxicity testing. Congenit Anom. 56:18-27.

Nishimura Y, Murakami S, Ashikawa Y, Sasagawa S, Umemoto N, Shimada Y, Tanaka T. 2015. Zebrafish as a systems toxicology model for developmental neurotoxicity testing. Congenit Anom (Kyoto). 55:1-16.

Nyman Y, Fredriksson A, Lonnqvist PA, Viberg H. 2016. Etomidate exposure in early infant mice $\left(\mathrm{P}_{10}\right)$ does not induce apoptosis or affect behaviour. Acta Anaesthesiol Scand. 60:588-596.

O'Shea KS, Kaufman MH. 1980. Neural tube closure defects following in vitro exposure of mouse embryos to xylocaine. J Exp Zool. 214: 235-238. 
Oggier DM, Weisbrod CJ, Stoller AM, Zenker AK, Fent K. 2010. Effects of diazepam on gene expression and link to physiological effects in different life stages in zebrafish Danio rerio. Environ Sci Technol. 44: 7685-7691.

Olsen EA, Brambrink AM. 2013. Anesthetic neurotoxicity in the newborn and infant. Curr Opin Anaesthesiol. 26:535-542.

Oosterhof N, Boddeke E, van Ham TJ. 2015. Immune cell dynamics in the CNS: learning from the zebrafish. Glia 63:719-735.

Ostrer H, Wilson DI, Hanley NA. 2006. Human embryo and early fetus research. Clin Genet. 70:98107.

Panula P, Chen YC, Priyadarshini M, Kudo H, Semenova S, Sundvik M, Sallinen V. 2010. The comparative neuroanatomy and neurochemistry of zebrafish CNS systems of relevance to human neuropsychiatric diseases. Neurobiol Dis. 40:46-57.

Perna RB, Loughan AR, Le JA, Hertza J. 2015. Prenatal and perinatal anesthesia and the long-term cognitive sequelae: a review. Appl Neuropsychol Child. 4:65-71.

Postlethwait J, Amores A, Cresko W, Singer A, Yan YL. 2004. Subfunction partitioning, the teleost radiation and the annotation of the human genome. Trends Genet. 20:481-490.

Przewlocki R. 2004. Opioid abuse and brain gene expression. Eur J Pharmacol. 500:331-349.

Ramazzotto LJ, Curro FA, Paterson JA, Tanner P, Coleman M. 1985. Toxicological assessment of lidocaine in the pregnant rat. J Dent Res. 64:1214-1217.

Rand-Weaver M, Margiotta-Casaluci L, Patel A, Panter GH, Owen SF, Sumpter JP. 2013. The readacross hypothesis and environmental risk assessment of pharmaceuticals. Environ Sci Technol. 47:11384-11395.

Redmond C. 2014. 'One R' is the new 'Three Rs'. ATLA. 42:P50-2.

Reitman E, Flood P. 2011. Anaesthetic considerations for non-obstetric surgery during pregnancy. Br J Anaesth. 107:i72-8.

Renshaw SA, Loynes CA, Elworthy S, Ingham PW, Whyte MK. 2007. Modeling inflammation in the zebrafish: how a fish can help us understand lung disease. Exp Lung Res. 33:549-554.

Rico EP, Rosemberg DB, Seibt KJ, Capiotti KM, Da Silva RS, Bonan CD. 2011. Zebrafish neurotransmitter systems as potential pharmacological and toxicological targets. Neurotoxicol Teratol. 33:608-617.

Ritter LM, Unis AS, Meador-Woodruff JH. 2001. Ontogeny of ionotropic glutamate receptor expression in human fetal brain. Brain Res Dev Brain Res. 127:123-133. 
Robinson BL, Dumas M, Ali SF, Paule MG, Gu Q, Kanungo J. 2018. Mechanistic studies on ketamineinduced mitochondrial toxicity in zebrafish embryos. Neurotoxicol Teratol. 69:63-72.

Robinson BL, Dumas M, Cuevas E, Gu Q, Paule MG, Ali SF, Kanungo J. 2016. Distinct effects of ketamine and acetyl L-carnitine on the dopamine system in zebrafish. Neurotoxicol Teratol. 54:5260.

Robinson B, Dumas M, Gu Q, Kanungo J. 2018. N-acetylcysteine prevents ketamine-induced adverse effects on development, heart rate and monoaminergic neurons in zebrafish. Neurosci Lett. 682:5661.

Robinson BL, Dumas M, Paule MG, Ali SF, Kanungo J. 2015. Opposing effects of ketamine and acetyl $\mathrm{L}$-carnitine on the serotonergic system of zebrafish. Neurosci Lett. 607:17-22.

Robinson BL, Dumas M, Ali SF, Paule MG, Gu Q, Kanungo J. 2017. Cyclosporine exacerbates ketamine toxicity in zebrafish: mechanistic studies on drug-drug interaction. J Appl Toxicol. 37(12):1438-1447.

Rodriguez F, Lopez JC, Vargas JP, Broglio C, Gomez Y, Salas C. 2002. Spatial memory and hippocampal pallium through vertebrate evolution: insights from reptiles and teleost fish. Brain Res Bull. 57:499-503.

Saint-Amant L. 2006. Development of motor networks in zebrafish embryos. Zebrafish. 3:173-190. Saint-Amant L, Drapeau P. 1998. Time course of the development of motor behaviors in the zebrafish embryo. J Neurobiol. 37:622-632.

Saint-Raymond A, de Vries CS. 2016. Medicine safety in pregnancy and ambitions for the EU medicine regulatory framework. Clin Pharmacol Ther. 100:21-23.

Sanchez-Simon FM, Arenzana FJ, Rodriguez RE. 2010. In vivo effects of morphine on neuronal fate and opioid receptor expression in zebrafish embryos. Eur J Neurosci. 32:550-559.

Sanchez-Simon FM, Zhang XX, Loh HH, Law PY, Rodriguez RE. 2010. Morphine regulates dopaminergic neuron differentiation via miR133b. Mol Pharmacol. 78:935-942.

Sanders RD, Hassell J, Davidson AJ, Robertson NJ, Ma D. 2013. Impact of anaesthetics and surgery on neurodevelopment: an update. Br J Anaesth. 110 (Suppl 1):i53-72.

Schechtman LM. 2002. Implementation of the 3 Rs (refinement, reduction, and replacement): validation and regulatory acceptance considerations for alternative toxicological test methods. ILAR J. 43:S85-S94.

Schmidt R, Strahle U, Scholpp S. 2013. Neurogenesis in zebrafish - from embryo to adult. Neural Dev. $8: 3-3$.

Schneider H. 2017. Zebrafish neurobehavioral assays for drug addiction research. In: Kalueff AV, editor. The rights and wrongs of zebrafish: behavioral phenotyping of zebrafish. Cham: Springer International Publishing; p. 171-205. 
Schubert S, Keddig N, Hanel R, Kammann U. 2014. Microinjection into zebrafish embryos (Danio rerio) - a useful tool in aquatic toxicity testing? Env Sci Eur. 26:1-8.

Schumann J. 2010. Teratogen screening: state of the art. Avicenna J Med Biotechnol. 2:115-121.

Semple BD, Blomgren K, Gimlin K, Ferriero DM, Noble-Haeusslein LJ. 2013. Brain development in rodents and humans: identifying benchmarks of maturation and vulnerability to injury across species. Prog Neurobiol. 106-107:1-16.

Sleigh J, Harvey M, Voss L, Denny B. 2014. Ketamine - more mechanisms of action than just NMDA blockade. Trends Anaesth Critic Care. 4: 76-81.

Smith RF, Kurkjian MF, Mattran KM, Kurtz SL. 1989. Behavioral effects of prenatal exposure to lidocaine in the rat: effects of dosage and of gestational age at administration. Neurotoxicol Teratol. 11:395-403.

Sneddon LU. 2012. Clinical anesthesia and analgesia in fish. J Exot Pet Med. 21:32-43.

Soares J, Coimbra AM, Reis-Henriques MA, Monteiro NM, Vieira MN, Oliveira JM, Guedes-Dias P, Fontainhas-Fernandes A, Parra SS, Carvalho AP, et al. 2009. Disruption of zebrafish (Danio rerio) embryonic development after full life-cycle parental exposure to low levels of ethinylestradiol. Aquat Toxicol. 95:330-338.

Spence R, Gerlach G, Lawrence C, Smith C. 2008. The behaviour and ecology of the zebrafish, Danio rerio. Biol Rev Camb Philos Soc. 83:13-34.

Stackley KD, Beeson CC, Rahn JJ, Chan SS. 2011. Bioenergetic profiling of zebrafish embryonic development. PLoS One. 6:e25652.

Stewart A, Wong K, Cachat J, Gaikwad S, Kyzar E, Wu N, Hart P, Piet V, Utterback E, Elegante M, et al. 2011. Zebrafish models to study drug abuse-related phenotypes. Rev Neurosci. 22:95-105.

Strahle U, Scholz S, Geisler R, Greiner P, Hollert H, Rastegar S, Schumacher A, Selderslaghs I, Weiss $\mathrm{C}$, Witters $\mathrm{H}$, Braunbeck T. 2012. Zebrafish embryos as an alternative to animal experiments-a commentary on the definition of the onset of protected life stages in animal welfare regulations. Reprod Toxicol. 33:128-132.

Su F, El-Komy MH, Hammer GB, Frymoyer A, Cohane CA, Drover DR. 2015. Population pharmacokinetics of etomidate in neonates and infants with congenital heart disease. Biopharm Drug Dispos. 36: 104-114.

Sun L. 2010. Early childhood general anaesthesia exposure and neurocognitive development. Br J Anaesth. 105:i61-8.

Taylor KL, Grant NJ, Temperley ND, Patton EE. 2010. Small molecule screening in zebrafish: an in vivo approach to identifying new chemical tools and drug leads. Cell Commun Signal. 8:11. 
Teiling AK, Mohammed AK, Minor BG, Jarbe TU, Hiltunen AJ, Archer T. 1987. Lack of effects of prenatal exposure to lidocaine on development of behavior in rats. Anesth Analg. 66:533-541.

Tobias JD. 2015. Etomidate in pediatric anesthesiology: Where are we now? Saudi J Anaesth. 9:451456.

Trickler WJ, Guo X, Cuevas E, Ali SF, Paule MG, Kanungo J. 2014. Ketamine attenuates cytochrome p450 aromatase gene expression and estradiol-17beta levels in zebrafish early life stages. J Appl Toxicol. 34:480-488.

Tropepe V, Sive HL. 2003. Can zebrafish be used as a model to study the neurodevelopmental causes of autism? Genes Brain Behav. 2: 268-281.

Truong L, Harper SL, Tanguay RL. 2011. Evaluation of embryotoxicity using the zebrafish model. Methods Mol Biol. 691:271-279.

Upadya M, Saneesh PJ. 2016. Anaesthesia for non-obstetric surgery during pregnancy. Indian J Anaesth. 60:234-241.

Veldman MB, Lin S. 2008. Zebrafish as a developmental model organism for pediatric research. Pediatr Res. 64:470-476.

Verbueken E, Alsop D, Saad MA, Pype C, Van Peer EM, Casteleyn CR, Van Ginneken CJ, Wilson J, Van Cruchten SJ. 2017. In vitro biotransformation of two human сурза probe substrates and their inhibition during early zebrafish development. IJMS 18:217.

Vilela SM, Santos DJ, Felix L, Almeida JM, Antunes L, Peixoto F. 2009. Are fentanyl and remifentanil safe opioids for rat brain mitochondrial bioenergetics? Mitochondrion 9:247-253.

Vliegenthart AD, Tucker CS, Del Pozo J, Dear JW. 2014. Zebrafish as model organisms for studying drug-induced liver injury. Br J Clin Pharmacol. 78:1217-1227.

Vutskits L, Davidson A. 2017. Update on developmental anesthesia neurotoxicity. Curr Opin Anaesthesiol. 30:337-342.

Walton NKD, Melachuri VK. 2006. Anaesthesia for non-obstetric surgery during pregnancy. Continuing education in anaesthesia. Critical Care Pain. 6:83-85.

Westerfield M. 2000. The zebrafish book. A guide for the laboratory use of zebrafish (Danio rerio). Eugene, OR: University of Oregon Press.

Wolman MA, Jain RA, Liss L, Granato M. 2011. Chemical modulation of memory formation in larval zebrafish. Proc Natl Acad Sci USA. 108: 15468-15473.

Woods IG, Kelly PD, Chu F, Ngo-Hazelett P, Yan YL, Huang H, Postlethwait JH, Talbot WS. 2000. A comparative map of the zebrafish genome. Genome Res. 10:1903-1914. 
Yazdy MM, Desai RJ, Brogly SB. 2015. Prescription opioids in pregnancy and birth outcomes: a review of the literature. J Pediatr Genet. 4: 56-70.

Yu D, Jiang Y, Gao J, Liu B, Chen P. 2013. Repeated exposure to propofol potentiates neuroapoptosis and long-term behavioral deficits in neonatal rats. Neurosci Lett. 534:41-46.

Zahid H, Tsang B, Ahmed H, Lee RCY, Tran S, Gerlai R. 2018. Diazepam fails to alter anxiety-like responses but affects motor function in a white-black test paradigm in larval zebrafish (Danio rerio). Prog Neuropsychopharmacol Biol Psychiatry 83:127-136.

Zhou P, Jiang J, Yan H, Li Y, Zhao J, Wang X, Su R, Gong Z. 2018. ABIN-1 negatively regulates I-opioid receptor function. Mol Pharmacol. 93: 36-48.

Zhou Z, Ma D. 2014. Anaesthetics-induced neurotoxicity in developing brain: an update on preclinical evidence. Brain Sci. 4:136-149. 
Table 1: Experimental studies carried out over the last years on the developmental effects of anaesthetic exposure in the zebrafish during early developmental stages.

\begin{tabular}{|c|c|c|c|c|c|c|}
\hline Anaesthetic & End Point & Zebrafish stage & $\begin{array}{l}\text { Concentration } \\
\text { tested (mM) }\end{array}$ & $\begin{array}{l}\text { Exposure } \\
\text { duration } \\
\text { (min) }\end{array}$ & Key observations & Reference \\
\hline \multirow{14}{*}{ Ketamine } & \multirow{14}{*}{$\begin{array}{l}\text { Developmental } \\
\text { phenotyping }\end{array}$} & Pharyngula (26 hpf) & \multirow{3}{*}{$0.5-10$} & 120 and & Roce-denendent attenuation of heart rate & \multirow{3}{*}{ (Kanungo et al., 2012) } \\
\hline & & Hatching (52 hpf) & & 1200 & Dose-dependent attenuatıon of heart rate & \\
\hline & & Hatching (52 hpf) & & 1200 & Significant reduction in ERK/MAPK activity & \\
\hline & & Pharyngula (28 hpf) & $0.5-2.0$ & 1200 & $\begin{array}{l}\text { Dose-dependent reduction in primary sensory } \\
\text { Rohon-Beard neuron and spinal motor neuron } \\
\text { populations }\end{array}$ & (Cuevas et al., 2013) \\
\hline & & Pharyngula (28 hpf) & $0.5-2.0$ & 1200 & $\begin{array}{l}\text { Reduce of motor neuron axon length and } \\
\text { decrease both cranial and spinal motor neurons }\end{array}$ & (Kanungo et al., 2013) \\
\hline & & Blastula (2.5 hpf) & $0.84-3.37$ & 20 & $\begin{array}{l}\text { Concentration-dependent increase in anomalies } \\
\text { and mortality }\end{array}$ & $\begin{array}{l}\text { (Felix, Antunes, and } \\
\text { Coimbra, 2014) }\end{array}$ \\
\hline & & Blastula (2.5 hpf) & \multirow{3}{*}{$0.84-3 \cdot 37$} & \multirow{3}{*}{20} & $\begin{array}{l}\text { Stage-dependent bone } \\
\text { malformations }\end{array}$ and cartilage & \multirow{3}{*}{ (Felix et al., 2016) } \\
\hline & & Gastrula (5.5 hpf) & & & $\begin{array}{l}\text { Concentration-dependent } \\
\text { malformations }\end{array}$ & \\
\hline & & Segmentation (10.5 hpf) & & & Non-specific malformations & \\
\hline & & Blastula (2.5 hpf) & $0.21-0.38$ & 1440 & $\begin{array}{l}\text { Increased mortality, oedema, heart rate } \\
\text { alterations and abnormal growth rates } \\
\text { Dose-dependent abnormalities } \\
\end{array}$ & (Felix et al., 2017) \\
\hline & & Gastrula (6 hpf) & \multirow[b]{2}{*}{2.0} & 1440 & $\begin{array}{l}\text { Developmental toxicity with animals showing } \\
\text { less pigmentation and smaller eyes }\end{array}$ & \multirow[b]{2}{*}{ (Robinson et al., 2017) } \\
\hline & & Pharyngula (24 hpf) & & 4320 & $\begin{array}{l}\text { Developmental toxicity presenting edematous } \\
\text { pericardium and significantly reduced linear body } \\
\text { length }\end{array}$ & \\
\hline & & Hatching (48 hpf) & 2.0 & 20 & Significantly reduced heart rate & (Robinson et al., 2018) \\
\hline & & Pharyngula (28 hpf) & 2.0 & 1200 & Altered heart development & (Robinson et al., 2018) \\
\hline
\end{tabular}




\begin{tabular}{|c|c|c|c|c|c|}
\hline \multirow{6}{*}{$\begin{array}{l}\text { Behavioural } \\
\text { phenotyping }\end{array}$} & Larval (6 dpf) & $0-3$ & $10-20$ & $\begin{array}{l}\text { Impairment of prepulse inhibition and altered } \\
\text { sensorimotor gating }\end{array}$ & $\begin{array}{c}\text { (Burgess and Granato, } \\
2007 \text { ) }\end{array}$ \\
\hline & Larval (6 dpf) & 0.5 & 15 & $\begin{array}{l}\text { Dose-dependent and reversible reduction in } \\
\text { startle habituation and startle sensitivity }\end{array}$ & (Wolman et al., 2011) \\
\hline & Blastula (2.5 hpf) & \multirow{3}{*}{$0.84-3.37$} & \multirow{3}{*}{20} & $\begin{array}{l}\text { Dose-dependent decrease in the overall mean } \\
\text { speed }\end{array}$ & \multirow{3}{*}{ (Felix et al., 2017) } \\
\hline & Gastrula (5.5 hpf) & & & $\begin{array}{l}\text { Concentration-related increment of the anxiety- } \\
\text { like behaviour }\end{array}$ & \\
\hline & Segmentation (10.5 hpf) & & & $\begin{array}{llll}\begin{array}{l}\text { Dose-dependent } \\
\text { behaviour }\end{array} & \text { decrease in avoidance } \\
\end{array}$ & \\
\hline & Blastula (2.5 hpf) & $0.21-0.38$ & 1440 & $\begin{array}{l}\text { Concentration-related increase in thigmotaxis } \\
\text { and disruption of avoidance behaviour }\end{array}$ & (Felix et al., 2017) \\
\hline Bioenergetics & Pharyngula (28 hpf) & 2.0 & 1200 & $\begin{array}{l}\text { Reduced ATP levels } \\
\text { Reduced mitochondrial proteins and membrane } \\
\text { potential } \\
\text { Increased ATP synthase protein levels }\end{array}$ & (Robinson et al., 2018) \\
\hline \multirow{8}{*}{ Gene expression } & Pharyngula (28 hpf) & $0.5-2.0$ & 1200 & Altered expression of proneural genes & (Kanungo et al., 2013) \\
\hline & Hatching ( 48 hpf) & 2.0 & 1440 & $\begin{array}{l}\text { Altered expression of cyp19 aromatases and } \\
\text { reduction in p-ERK levels } \\
\text { reduction in } \mathrm{p} \text {-ERK levels }\end{array}$ & (Trickler et al., 2014) \\
\hline & Pharyngula (28 hpf) & \multirow{2}{*}{2.0} & \multirow{2}{*}{1200} & Altered expression of atpa $\alpha_{1}$ and $a_{t p} b$ & (Robinson et al., 2018) \\
\hline & Larval (72 hpf) & & & Dose-dependent increase of cypзa65 expression & (Robinson et al., 2017) \\
\hline & Blastula (2.5 hpf) & \multirow{3}{*}{$0.84-3 \cdot 37$} & \multirow{3}{*}{20} & $\begin{array}{l}\text { Up-regulation of apoptosis and proliferative } \\
\text { mRNA levels } \\
\text { Altered expression of sonic hedgehog and noggin }\end{array}$ & \multirow{3}{*}{$\begin{array}{l}\text { (Felix et al., 2016; Felix et } \\
\text { al., 2017; Felix et al., 2016) }\end{array}$} \\
\hline & Gastrula (5.5 hpf) & & & $\begin{array}{l}\text { Increased caspg, aifm1, tp53 and pcna levels } \\
\text { Altered expression of sonic hedgehog }\end{array}$ & \\
\hline & Segmentation (10.5 hpf) & & & $\begin{array}{l}\text { No meaningful changes on transcript levels } \\
\text { Altered expression of sonic hedgehog Dose- } \\
\text { dependent up-regulation of cat gene expression } \\
\text { Altered expression of sodı gene }\end{array}$ & \\
\hline & Pharyngula (28 hpf) & 2.0 & 1200 & Altered ATP synthase gene expression & (Robinson et al., 2018) \\
\hline
\end{tabular}




\begin{tabular}{|c|c|c|c|c|c|}
\hline \multirow{4}{*}{$\begin{array}{l}\text { Oxidative stress } \\
\text { indicators }\end{array}$} & Blastula (2.5 hpf) & \multirow{3}{*}{$0.84-3.37$} & \multirow{3}{*}{20} & Dose-related increase in GSH levels & \multirow{3}{*}{ (Felix et al., 2016) } \\
\hline & Gastrula (5.5 hpf) & & & Increase in SOD and CAT enzymatic activities & \\
\hline & Segmentation (10.5 hpf) & & & Dose-dependent increase in ROS production & \\
\hline & Blastula (2.5 hpf) & $0.21-0.38$ & 1440 & $\begin{array}{l}\text { Induction of oxidative stress and apoptosis } \\
\text { through the involvement of p53-dependent } \\
\text { pathways }\end{array}$ & (Felix et al., 2018) \\
\hline \multirow{4}{*}{$\begin{array}{l}\text { Neurotransmitter } \\
\text { metabolic activity }\end{array}$} & Hatching ( $52 \mathrm{hpf}$ ) & $0.1-2.0$ & 1444 & $\begin{array}{l}\text { Dose-dependent modulation of } 5-\mathrm{HT} \text { and } 5-\mathrm{HIAA} \\
\text { levels } \\
\text { Reduction of the serotonergic area in the brain }\end{array}$ & (Robinson et al., 2015) \\
\hline & Hatching (52 hpf) & $0.1-2.0$ & 1444 & $\begin{array}{l}\text { Reduction of dopamine levels and altered } \\
\text { expression of genes related to tyrosine } \\
\text { hydroxylase and dopamine metabolizing enzyme }\end{array}$ & (Robinson et al., 2016) \\
\hline & Segmentation (10.5 hpf) & $0.84-3.37$ & 20 & Acetylcholinesterase activity changes & (Felix et al., 2016) \\
\hline & Hatching (48 hpf) & 2.0 & 1200 & $\begin{array}{l}\text { Reduced serotonergic neurons in the brain } \\
\text { Significant reduction of TH-IR neurons in the } \\
\text { embryo brain }\end{array}$ & (Robinson et al., 2018) \\
\hline $\begin{array}{l}\text { Developmental } \\
\text { phenotyping }\end{array}$ & \multirow[t]{2}{*}{ Gastrula (6 hpf) } & \multirow[t]{2}{*}{$0.001-0.009$} & \multirow[t]{2}{*}{2520} & $\begin{array}{l}\text { Dose-dependent decrease in hatchability } \\
\text { Increased aberrations } \\
\text { Increased apoptosis }\end{array}$ & \multirow{2}{*}{$\begin{array}{l}\text { (Guo et al., 2015; Liv et al., } \\
\text { 2018) }\end{array}$} \\
\hline Gene expression & & & & $\begin{array}{l}\text { Inhibition of the expression of myelin basic } \\
\text { protein }\end{array}$ & \\
\hline $\begin{array}{l}\text { Behavioural } \\
\text { phenotyping }\end{array}$ & Larval (6 dpf) & 0.003 to 0.1 & 10 to 120 & Dose-dependent loss of brain function & (Du et al., 2018) \\
\hline $\begin{array}{l}\text { Behavioural } \\
\text { phenotyping }\end{array}$ & Larval (6 dpf) & 0.003 to 0.1 & 10 to 120 & $\begin{array}{l}\text { Dose-dependent suppression of neuronal } \\
\text { activity }\end{array}$ & (Du et al., 2018) \\
\hline Pharmacokinetics & Larval (7 dpf) & 0.001 & 180 & Significant accumulation in animals & (Alderton et al., 2010) \\
\hline Gene expression & Cleavage & $\begin{array}{c}0.0001 \mu \mathrm{M} \text { and } \\
0.001\end{array}$ & 4320 & $\begin{array}{l}\text { Altered expression of genes involved in the } \\
\text { circadian rhythm }\end{array}$ & \multirow{2}{*}{ (Oggier et al., 2010) } \\
\hline \multirow{2}{*}{$\begin{array}{l}\text { Behavioural } \\
\text { phenotyping }\end{array}$} & Cleavage & $\begin{array}{c}0.0001 \mu \mathrm{M} \text { and } \\
0.001\end{array}$ & 4320 & $\begin{array}{l}\text { Increased locomotor activity at high } \\
\text { concentration }\end{array}$ & \\
\hline & Larval (5-6 dpf) & $\begin{array}{c}0.25 \mu \mathrm{M} \text { and } 2.5 \\
\mu \mathrm{M}\end{array}$ & 45 & Significant motor activity reducing effect & (Zahid et al., 2018) \\
\hline
\end{tabular}




\begin{tabular}{|c|c|c|c|c|c|c|}
\hline Isoflurane & Toxicity testing & Larval (7 dpf) & $0-271$ & 15 & $\mathrm{LC}_{50}$ calculated as $135 \mathrm{mM}$ and $\mathrm{EC}_{50}$ as $14.2 \mathrm{mM}$ & (Ku et al., 2013) \\
\hline \multirow{9}{*}{ Morphine } & \multirow{2}{*}{$\begin{array}{l}\text { Developmental } \\
\text { phenotyping }\end{array}$} & Blastula ( 5 hpf) & $\begin{array}{c}0.001 \mu \mathrm{M}- \\
0.0001\end{array}$ & $\begin{array}{l}1140 \text { and } \\
2580\end{array}$ & Dose-dependent malformations and mortality & $\begin{array}{c}\text { (Jimenez-Gonzalez et al., } \\
\text { 2018; Sanchez-Simon, } \\
\text { Arenzana, and Rodriguez, } \\
\text { 2010) } \\
\end{array}$ \\
\hline & & Blastula ( 5 hpf) & 0.010 & 1140 & Delayed neural stem cells differentiation & $\begin{array}{c}\text { (Jimenez-Gonzalez et al., } \\
\text { 2018(Sanchez-Simon, } \\
\text { Arenzana, and Rodriguez, } \\
\text { 2010) } \\
\end{array}$ \\
\hline & \multirow{2}{*}{$\begin{array}{l}\text { Behavioural } \\
\text { phenotyping }\end{array}$} & Larval (5 dpf) & 0.035 & 40 & \multirow{2}{*}{ Hyperlocomotion } & (Lopez-Luna et al., 2017) \\
\hline & & Larval (7 dpf) & 0.350 & 60 & & (Zhou et al., 2018) \\
\hline & \multirow{5}{*}{ Gene expression } & Blastula ( 5 hpf) & $\begin{array}{c}0.001 \mu \mathrm{M}- \\
0.0001\end{array}$ & $\begin{array}{l}1140 \text { and } \\
2580\end{array}$ & Altered gene expression of the opioid receptors & $\begin{array}{c}\text { (Sanchez-Simon, } \\
\text { Arenzana, and Rodriguez, } \\
\text { 2010) }\end{array}$ \\
\hline & & Cleavage (1 hpf) & 0.001 and 0.01 & 1440 & $\begin{array}{l}\text { Dose-dependent regulation of multiple } \\
\text { MicroRNAs }\end{array}$ & $\begin{array}{l}\text { (Sanchez-Simon et al., } \\
\text { 2010) }\end{array}$ \\
\hline & & Blastula (5 hpf) & 0.01 & 1140 & $\begin{array}{l}\text { Altered expression of zebrafish-specific } \\
\text { morphine-induced genes }\end{array}$ & $\begin{array}{l}\text { (Herrero-Turrion et al., } \\
\text { 2014) }\end{array}$ \\
\hline & & Cleavage (1 hpf) & $\begin{array}{c}0.000035 \text { to } \\
0.035\end{array}$ & 5760 & $\begin{array}{l}\text { Altered expression of inflammation-related } \\
\text { genes } \\
\text { Decreased levels of inflammatory mediators }\end{array}$ & (Mottaz et al., 2017) \\
\hline & & Blastula (5 hpf) & 0.010 & 1140 & $\begin{array}{l}\text { Overexpression of the pluripotency transcription } \\
\text { factors }\end{array}$ & $\begin{array}{c}\text { (Jimenez-Gonzalez et al., } \\
2018\end{array}$ \\
\hline
\end{tabular}

Abbreviations: hpf: hours post-fertilization; dpf: days post-fertilization 